\title{
Modern pollen data from Tuchola Forest
}

\author{
Anna Filbrandt-Czaja \\ Nicolaus Copernicus University, Faculty of Biology and Environmental Protection, \\ Chair of Geobotany and Landscape Planning, \\ 87-100 Toruń, ul. Lwowska 1, Poland \\ e-mail: afczaja@umk.pl
}

Received: 15 April 2017/Accepted: 14 June 2017

\begin{abstract}
This paper compares pollen spectra derived from modified Tauber traps and moss samples adjacent to pollen traps from four sites different in type of vegetation and openness of the landscape in Tuchola Forest. The length of the pollen deposition period covered by an individual moss sample was a matter of discussion, as well as accumulated values of pollen grains in green gametophytes (A) and basal part of moss (B). Compared to pollen traps, mosses tend to accumulate more Pinus grains. The investigated moss samples $(\mathrm{A}+\mathrm{B})$ usually contain pollen from a period between one and two years. Pine, spruce, oak and beech pollen deposited more pollen almost always in the subsample A.
\end{abstract}

Keywords: modern pollen deposition, moss samples, Tauber traps, Tuchola Forest

\section{Introduction}

One of the key tasks of contemporary palynology is to answer the question how pollen spectra reflect the composition of vegetation in the surrounding of the analyzed sites. The relationship between pollen spectra and vegetation is not a simple correlation, but it should be taken into account the influence of many factors. For better understanding complex relationship between the composition of the palynological samples and the plant communities, modern pollen spectra are analyzed. These include surface samples taken from the moss layer (moss polster) and samples of annual pollen deposition. These type of analyzes were carried out in the Tuchola Forest.

Modern pollen spectra from moss polsters from Tuchola Forest were analyzed within the set of data obtained at 44 sites (Hrynowiecka et al. 2007). The relationship between the modern pollen rain and the structure of phytocoenoses, in which pollen samples were collected was studied. The set of data included 27 pollen samples together with 27 rel- evés made with the Braun-Blanquet method from pine forests, 6 samples from edges of forest complexes, 2 from heathlands, 6 from dry meadows and 3 from wet meadows.

Pollen of Pinus sylvestris, Betula and Alnus were observed in all analysed spectra. The performed analyses revealed differences between the structure of a phytocoenosis and a pollen sample collected from this phytocoenosis.

The following studies (Nienartowicz et al. 2011) aimed to compare the relationship between vegetation and modern pollen rain in three types of phytocoenoses: heaths, young pine-birch growths and mature pine tree stands. For palynological analysis, samples were collected at 26 research sites, including 12 in the Tuchola Forest and 14 in the Torun Basin. At each site a relevé was made using the Braun-Blanquet method. The performed ordination with the method of principal component analysis (PCA) revealed quite big differences between the pollen samples collected in the same types of plant communities. In this analysis no distinct relation was recorded between the composition of a phytocoenosis and a pollen spectrum. The absence of 
such relationships is proved by the fact that only one species - Calluna vulgaris - demonstrated a strong association between the occurrence in a plant community and in a pollen sample.

Another paper (Filbrandt-Czaja et al. 2012) presents a comparison of annual pollen deposition in Tauber traps with the actual vegetation at two research sites - Laska and Widno, located in the northern part of the Zaborski Landscape Park. The studied sites were circular in shape with a radius of $2 \mathrm{~km}$ and an area of 1256 ha each. The size of area covered by pine, birch, alder, hornbeam and oak and the amount of pollen deposition of these trees were positively correlated at both sites. Comparison of the average annual pollen deposition of trees pollen from two sites demonstrate that the PAR (Pollen Accumulation Rate) values at the site Widno are higher for most of the studied arboreal species than those values at the Laska site, but these differences are statistically significant only in the case of birch and hornbeam.

The present study concerns the comparison between annual pollen deposition (PAR) in traps and pollen deposition in moss samples collected close to the traps. Few studies have compared the assemblages obtained from moss samples with assemblages from other surface sampling media (Boyd 1986; Cundill 1991; Tonkov et al. 2001; Räsänen et al. 2004; Cundill et al. 2006, Lisytsyna \& Hicks 2014, Pardoe et al. 2010).
Pollen traps require sampling collected over a number of years before the full implications of the pollen-vegetation relationships are revealed (Hicks 1985) whilst moss polsters are assumed to be reservoirs of several years of pollen and spore accumulation but with no definite time span (Braggio Morucchio et al. 1988). The length of time reflected by the pollen assemblage retrieved from moss is of particular interest. According to Cundill (1991) there is considerable disagreement in the literature over the age of the moss material collected for different studies.

The aim of this paper is answer the questions raised above: 1. How many years of pollen are represented in analyzed moss samples? 2. How many pollen grains contain the basal sections of moss?

\section{The study area}

The research was carried out in Tuchola Forest in northern Poland. This region is located between $17^{\circ} 24^{\prime} 35^{\prime \prime}$ and $18^{\circ} 27^{\prime} 08^{\prime \prime}$ east longitude and between $53^{\circ} 29^{\prime} 55^{\prime \prime}$ and $54^{\circ} 03^{\prime} 58^{\prime \prime}$ north latitude. Area of Tuchola Forest is ca. $5,000 \mathrm{~km}^{2}$ including one of the largest forest complexes in Poland. The forestation rate of this region amounts to over $50 \%$. More fertile habitats and forest stands rich in deciduous species were preserved mostly in the eastern part of the forest complex.

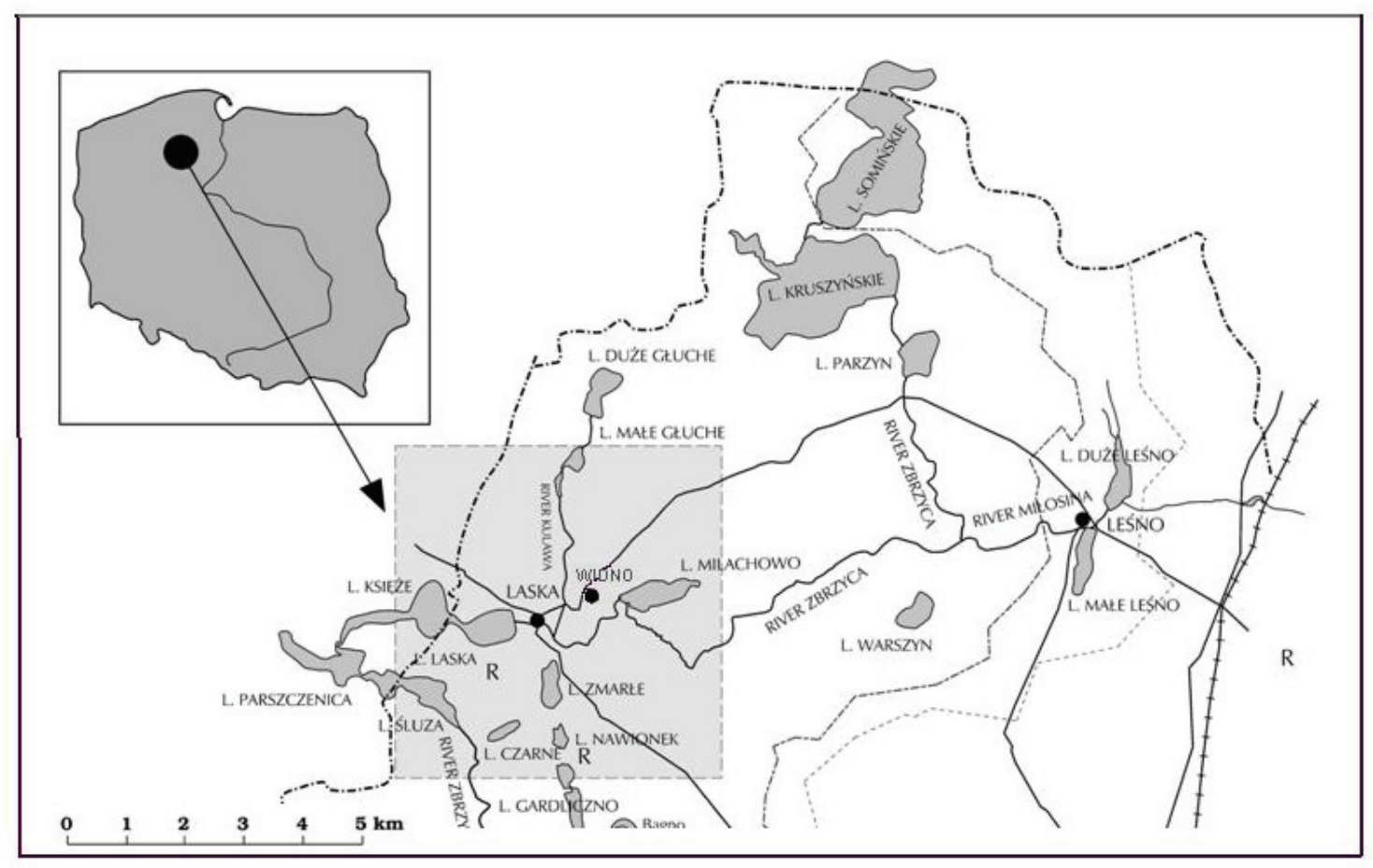

Figure 1. Location of the study area 
The mesoregion of Tuchola Forest includes a fragment of lowland Poland. It belongs to the macroregion of South Pomeranian Lake District and is situated in its eastern part, within the catchment area of the Wda River and partially of the Brda River (Kondracki 2000). In respect of climate, the Tuchola Forest region, is much drier and warmer as compared with areas of West Pomeranian and East Pomeranian Lake Districts. A young glacial, outwash type of natural landscape is characteristic for the Tuchola Forest. Those are extensive, sandy plains, in places with outcrops of moraine elevations. Another characteristic feature is the abundance and diversity of surface waters, with characteristic ribbon and kettle lakes, as well as raised and transitional peat bogs.

The Tuchola Forest is an extensive forest complex with the absolute domination of pine forests. Scots pine (Pinus sylvestris) constitutes about $95 \%$ of tree stands (Matuszkiewicz 1968). The species constituting the admixture in tree stands is pedunculate oak (Quercus robur) and European beech (Fagus silvatica); the latter one occurs here within a dispersed range.

A dominating habitat type in the Tuchola Forest is a fresh pine forest. The tree stand is usually composed of a single layer of Scots pine with a scanty admixture of European white birch (Betula pendula), without undergrowth, which is characteristic of even-aged plantings, or with undergrowth of common juniper (Juniperus communis), alder buckthorn (Frangula alnus) or European mountain ash (Sorbus aucuparia). In the herb layer, developed to a different extent, the following species dominate: bilberry (Vaccinium myrtillus), lingberry (Vaccinium vitisidaea), common heather (Calluna vulgaris). The vascular flora of the Tuchola Forest belongs to moderately rich floras. 1068 vascular plant species occur here, both native and domesticated ones (Ceynowa-Giełdon 1988).

\section{Methods}

Pollen deposition was monitored by four standardized pollen traps of Tauber's (1974) general design with modifications described by Hicks \& Hyvärinen (1986) and Hicks (1996). Two traps were located in the territory of the Laska village - in the open area (LO) and in the edge of forest (LE). In a similar way, two traps were placed in the periphery of the Widno village (WO and WE). The trap bottom was covered by a mixture of glycerine, thymol and formaline in the recommended proportions (Hicks et al. 1996). The traps remained in the field all year round (October-October) with the opening just above the ground surface. The trap contents were subjected to laboratory treatment followed by microscopic analysis. Lycopodium tablets were added at an early stage of laboratory treatment, followed by sieving through a coarse sieve, con- centration and Erdtman's acetolysis by standard methods used in pollen analysis. The addition of Lycopodium clavatum spores (Stockmarr 1971) during laboratory treatment permitted the calculation of PARs, frequently referred to as pollen influx values. The PAR is a number of pollen grains deposited on $1 \mathrm{~cm}^{2}$ of surface during 1 year (Hicks et al. 1999).

Moss samples have been collected adjacent to pollen traps in autumn 2011 in order to compare the pollen spectra from the two sampling media. Surface samples were collected in places overgrown with moss by means of a plastic cylinder with a diameter of $5 \mathrm{~cm}$ (the intersection area of $19.6 \mathrm{~cm}^{2}$ ). The number of samples taken at each station was dependent on the occurrence of places overgrown by the moss.

Samples collected in the field for palynological studies were transported to a laboratory. Each sample was divided into two subsamples: green gametophytes (A) and basal part of moss (B) (dead matter). Next, each sample was boiled in $10 \% \mathrm{KOH}$ solution. After boiling-out, samples were filtered out and rinsed with distilled water, and then two tablets of Lycopodium were added into. Next, the acetolysis of Erdtman was carried out on the studied samples in accordance with the recommendations of Berglund and Ralska-Jasiewiczowa (1986). Acetolysis is followed by staining the pollen grains with fuchsin, mounting in glycerine and microscopic analysis.

The pollen concentration of each taxon in surface samples was divided by the surface area and expressed as grains $\mathrm{cm}^{-2}$. These values could then be directly compared to successive annual deposition rates from the associated trap.

The analysis was based on pollen trap and moss sample results from the same year (2011).

\section{Results}

The sum of the deposition of pollen of herbaceous plants (NAP) in moss samples was the highest at the position Widno - Open, reaching a maximum value of 4785 grains $/ \mathrm{cm}^{2}$ in a sample WO-2, the smallest deposition of NAP were noted in the site Widno Edge (WE-5, 1476 grains / $\mathrm{cm}^{2}$ ). Average deposition of NAP in open space both in Laska (LO) and in Widno (WO), reached similar values. Inversely proportional are values of the deposition of trees (AP). The highest deposition of pollen grains of trees occurs at the positions Widno Edge (WE-1, 19317 grains / $\mathrm{cm}^{2}$ ), the lowest values in the Laska Open (LO-1, 4138 grains / cm 2). In all samples the highest values of the deposition reached the pollen of pine and birch. Analyzing the pollen deposition in the two layers (Table 1) can be concluded that in the case of pine, spruce, oak and beech more pollen is almost always occur in the upper layer- subsample A. In the case of other taxa such relation is less expressive. 
Table 1. Average deposition and standard deviation of selected pollen of trees and the sum of the NAP in layers A and B of surface samples

\begin{tabular}{|c|c|c|c|c|c|c|c|c|c|}
\hline $\begin{array}{c}\text { Site } \\
\text { and moss } \\
\text { layer }\end{array}$ & Pinus & Betula & Alnus & Quercus & Picea & Corylus & Carpinus & Fagus & $\Sigma$ NAP \\
\hline WE-A & $3693 \pm 1115$ & $1485 \pm 984$ & $608 \pm 612$ & $179 \pm 135$ & $1076 \pm 418$ & $659 \pm 497$ & $337 \pm 244$ & $243 \pm 48$ & $1025 \pm 278$ \\
\hline WE-B & $3856 \pm 1415$ & $4521 \pm 3223$ & $689 \pm 587$ & $118 \pm 148$ & $353 \pm 183$ & $805 \pm 578$ & $411 \pm 224$ & $160 \pm 94$ & $1367 \pm 406$ \\
\hline WO-A & $3930 \pm 1174$ & $288 \pm 92$ & $205 \pm 76$ & $266 \pm 118$ & $469 \pm 205$ & $62 \pm 15$ & $41 \pm 24$ & $234 \pm 61$ & $2148 \pm 287$ \\
\hline WO-B & $3210 \pm 1655$ & $320 \pm 490$ & $217 \pm 123$ & $150 \pm 128$ & $118 \pm 115$ & $49 \pm 71$ & $6 \pm 12$ & $200 \pm 299$ & $1547 \pm 682$ \\
\hline LE-A & $2673 \pm 1778$ & $1756 \pm 2075$ & $396 \pm 270$ & $207 \pm 83$ & $326 \pm 202$ & $320 \pm 365$ & $133 \pm 130$ & $164 \pm 99$ & $1277 \pm 1232$ \\
\hline LE-B & $2013 \pm 1065$ & $301 \pm 200$ & $139 \pm 72$ & $132 \pm 17$ & $146 \pm 51$ & $45 \pm 28$ & $14 \pm 9$ & $187 \pm 119$ & $839 \pm 645$ \\
\hline LO-A & $2164 \pm 720$ & $1123 \pm 895$ & $260 \pm 193$ & $167 \pm 56$ & $221 \pm 150$ & $195 \pm 176$ & $73 \pm 85$ & $231 \pm 95$ & $979 \pm 421$ \\
\hline LO-B & $1619 \pm 494$ & $859 \pm 1055$ & $160 \pm 101$ & $77 \pm 58$ & $133 \pm 76$ & $146 \pm 190$ & $51 \pm 68$ & $135 \pm 46$ & $905 \pm 299$ \\
\hline
\end{tabular}

\subsection{The site Laska Open}

The Tauber trap collecting the annual pollen deposition is located within mesophilic meadow with some admixture of xerothermic species, in the territory of the Laska village, which is surrounded by pine forest. Three samples from moss were collected near the pollen trap. All analysed trees achieved higher values of pollen deposition in subsample A consisting of living gametophytes (Fig. 2). Pinus sylves- tris pollen grains dominates in both subsamples (A and B), next in order is pollen of Picea.

Comparison between the pollen deposition of trees in the moss sample $(\mathrm{A}+\mathrm{B})$ and PAR in the pollen trap shows that the pollen accumulated in the moss was equivalent to less than 1 year's pollen deposition in the trap (Fig. 3).

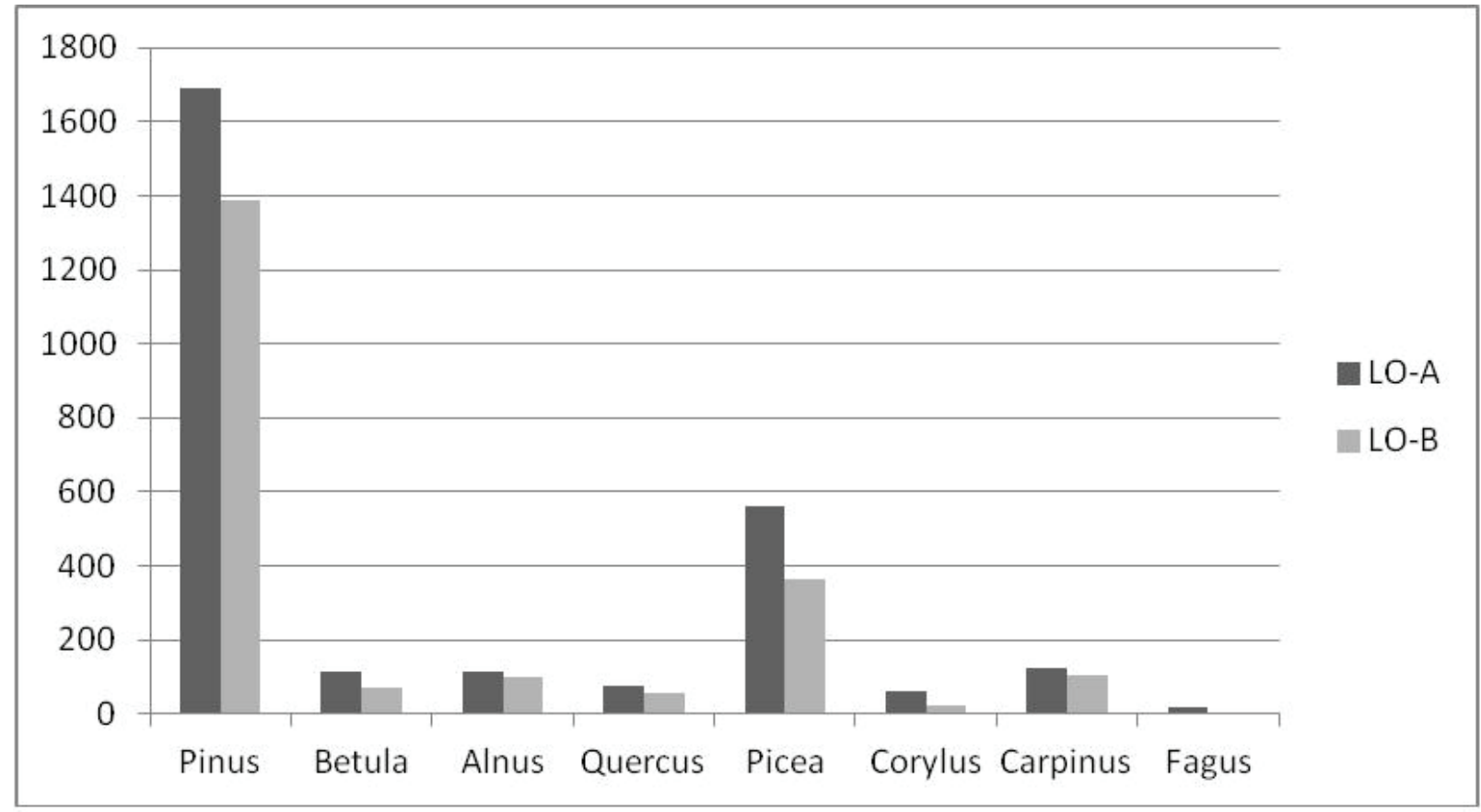

Figure 2. Average values of pollen deposition of selected trees in moss-polsters from Laska Open site in subsample A and B 


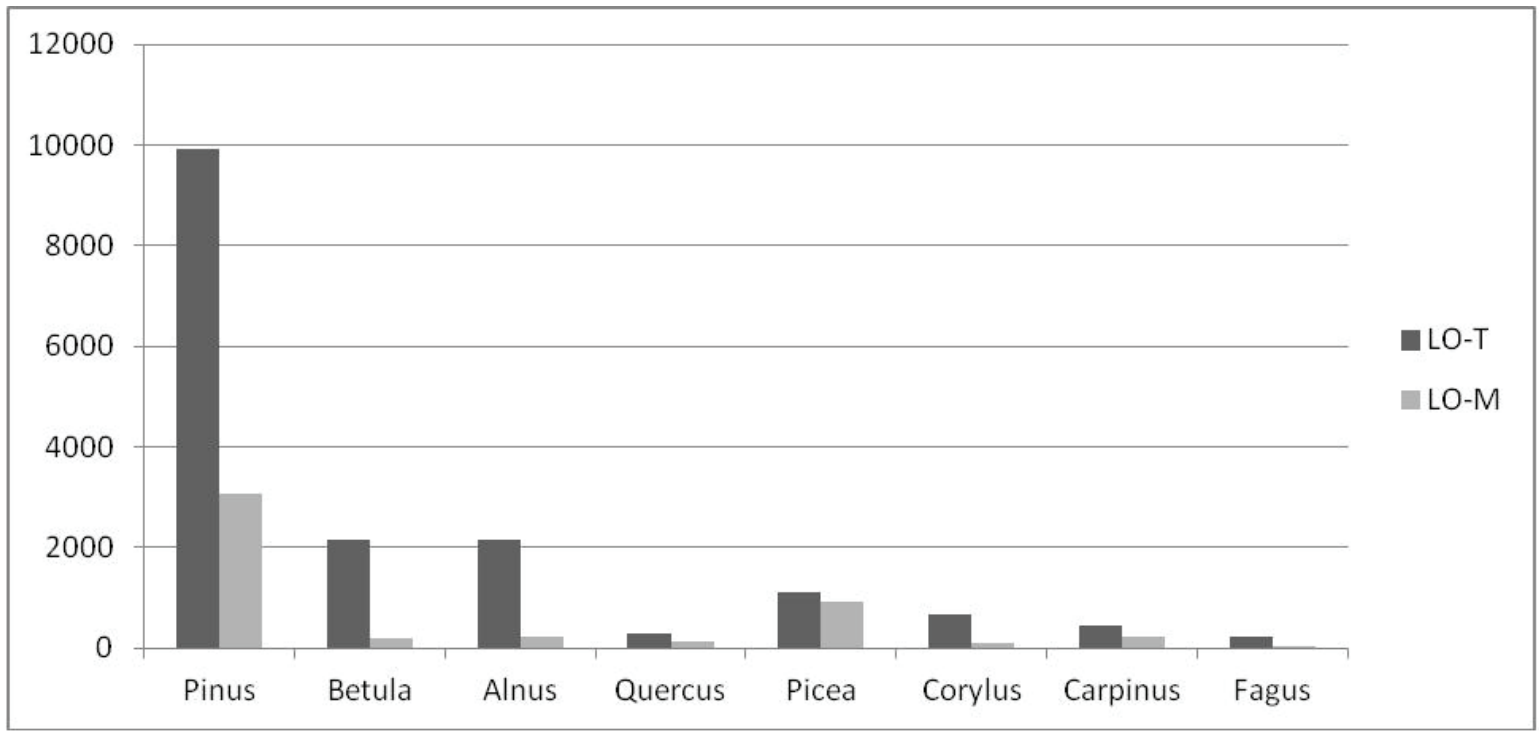

Figure 3. Difference between the pollen deposition of selected pollen taxa in the moss sample M (grains $\mathrm{cm}^{-2}$ ) and PAR in the pollen trap $\mathrm{T}$ (grains $\mathrm{cm}^{-2}$ year $^{-1}$ ) for the year of sample collection for sampling pairs from Laska Open site.

\subsection{The site Laska Edge}

The pollen trap is placed in the forest edge. In the northern part of the Laska village where traps were installed, fresh pine forest occurred with some admixture of deciduous trees - silver birch, small-leaved lime, beech and oak. Three samples from moss were collected near the pollen trap. In samples from this station average pollen accumulation of analyzed trees have found higher in subsample A, with the exception of Corylus, which achieved slightly higher values of deposition in subsample B (Fig. 4). Strong domination of Pinus pollen is noted in both subsamples.

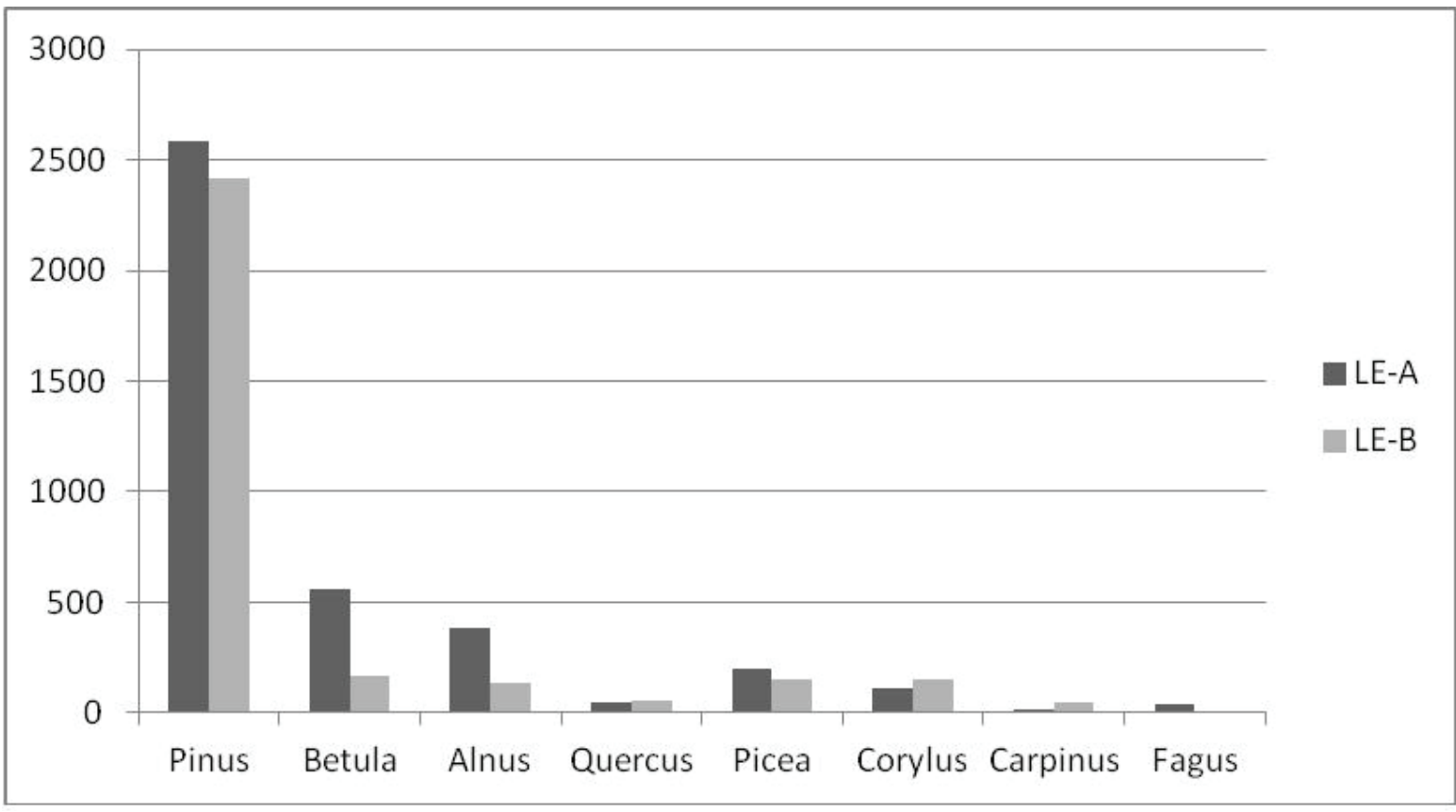

Figure 4. Average values of pollen deposition of selected trees in moss-polsters from Laska Edge site in subsample A and B 
A comparison of the pollen accumulation rate in pollen traps on Laska Edge station with the pollen concentration in the moss per unit surface indicates large differences for individual pollen taxa (Fig. 5). Pinus, Picea and Corylus deposit a slightly more pollen grains in the moss per unit surface compare with PAR values from trap, while Betula, Alnus and Fagus have a higher values of pollen accumulation in trap.

\subsection{The site Widno Open}

The Tauber trap is located within a wet meadow near Lake Milachowo at the periphery of the Widno village. Four samples from moss were collected in the near distance from the pollen trap. The average values of pollen deposition are higher in green gametophytes- subsample A (Fig. 6) than in subsample B (basal parts of mosses).

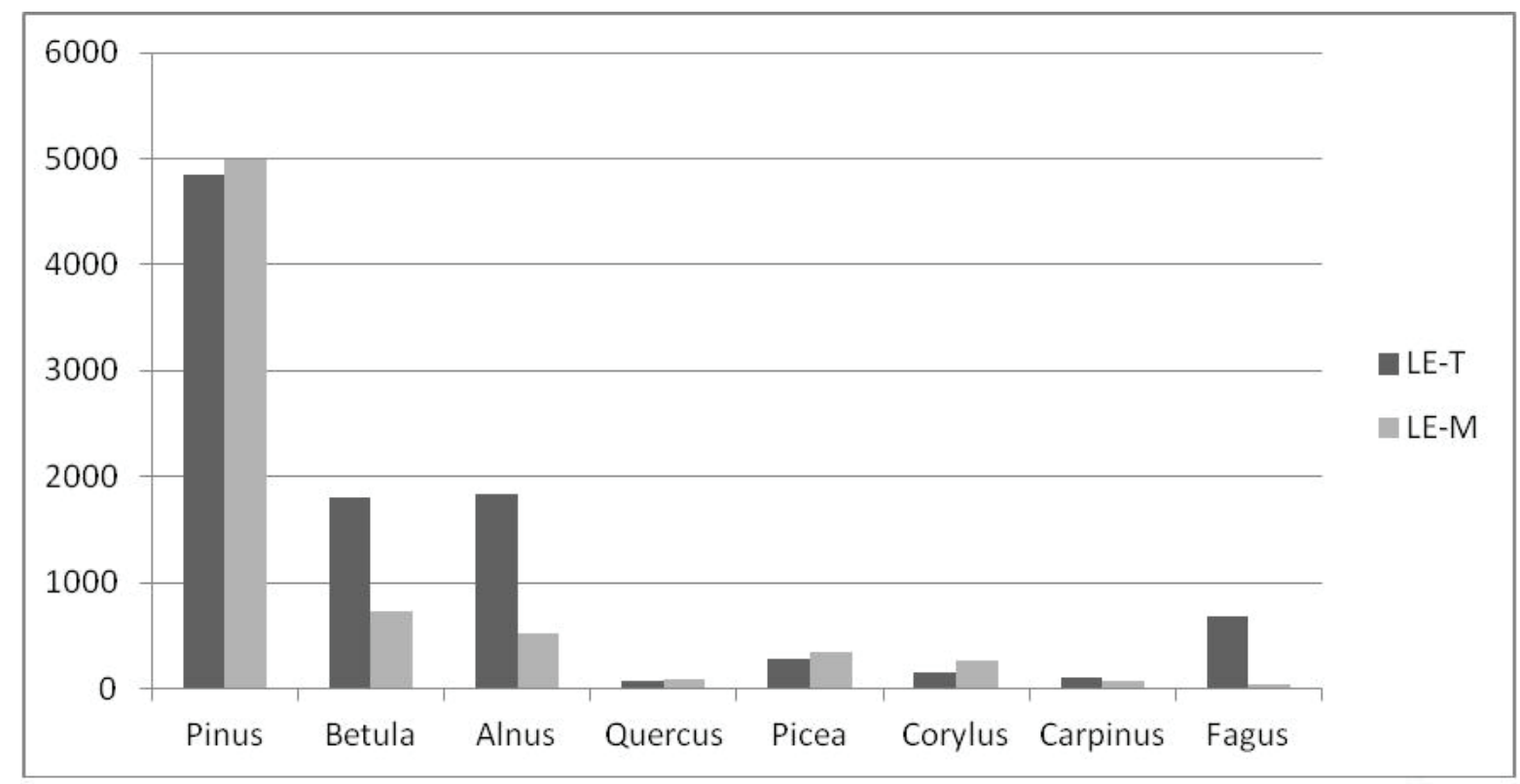

Figure 5. Differences between the pollen deposition in the moss sample $\mathrm{M}$ (grains $\mathrm{cm}^{-2}$ ) and PAR in the pollen trap T (grains $\mathrm{cm}^{-2}$ year-1) for the year of sample collection for sampling pairs from Laska Edge site

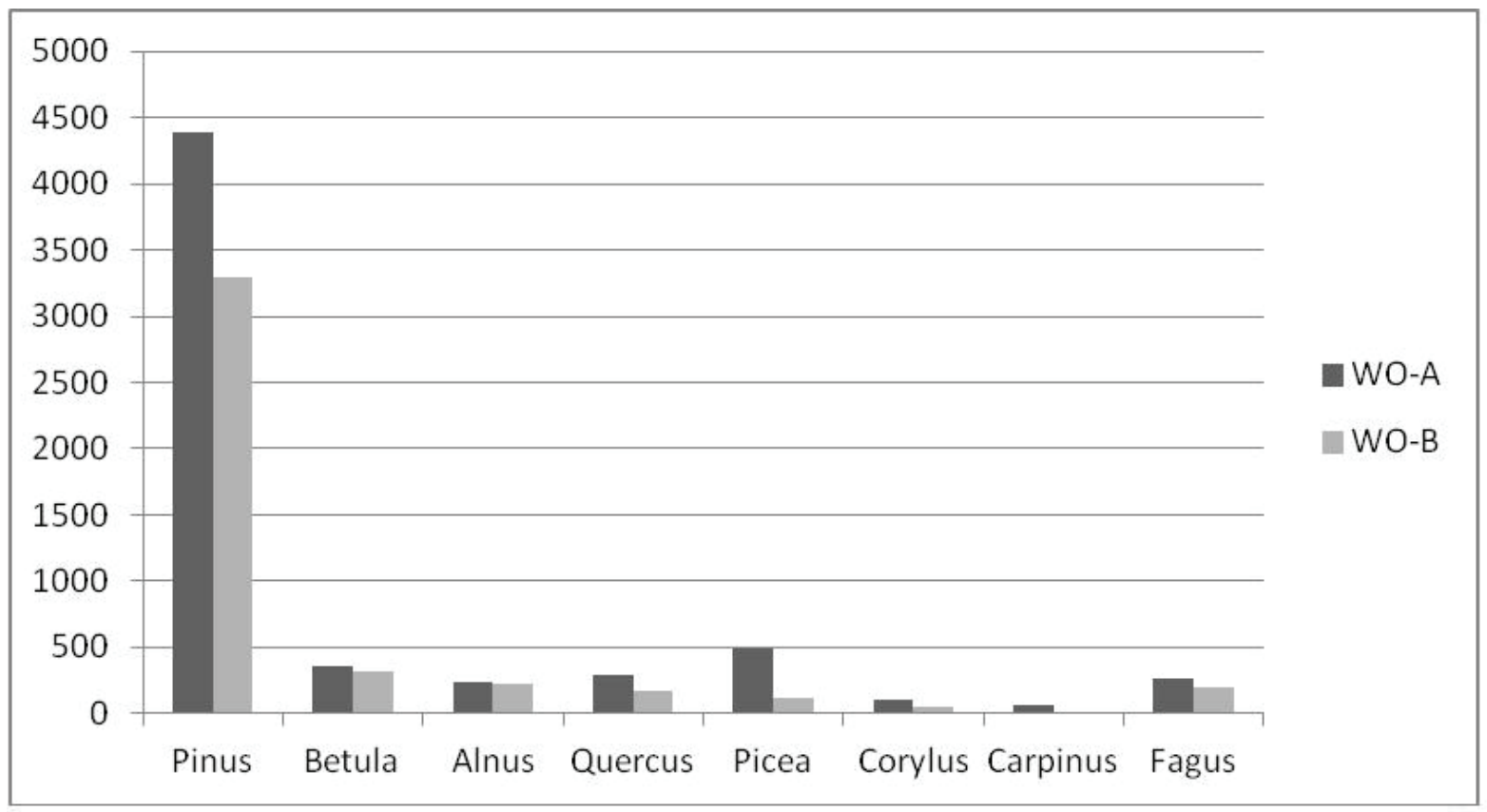

Figure 6. Average values of pollen deposition of selected trees in moss-polsters from Widno Open site in subsample A and B 


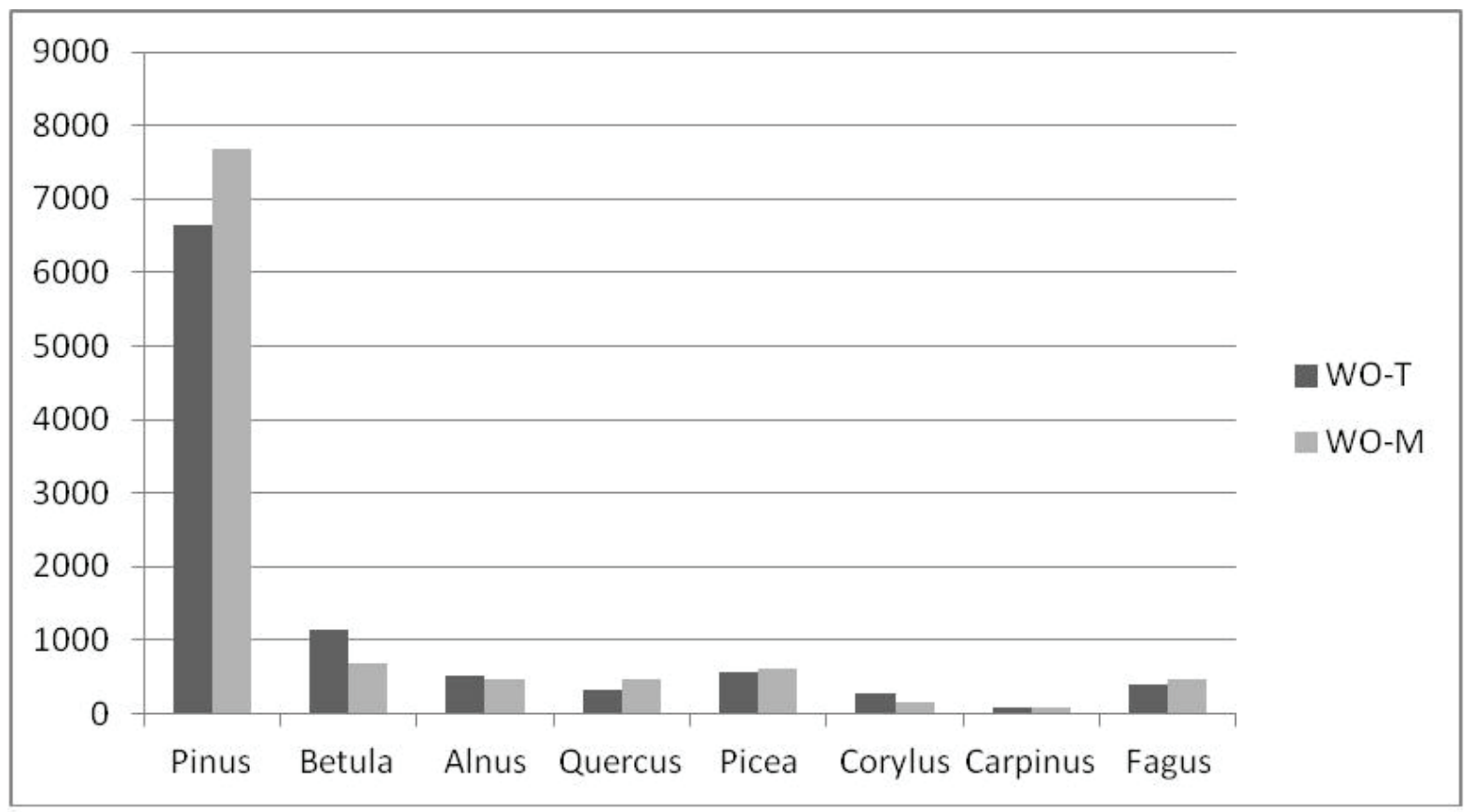

Figure 7. Difference between the pollen deposition in the moss sample $\mathrm{M}$ (grains $\mathrm{cm}^{-2}$ ) and PAR from the pollen trap $\mathrm{T}$ (grains cm-2 year-1) for the year of sample collection for sampling pairs from Widno Open site

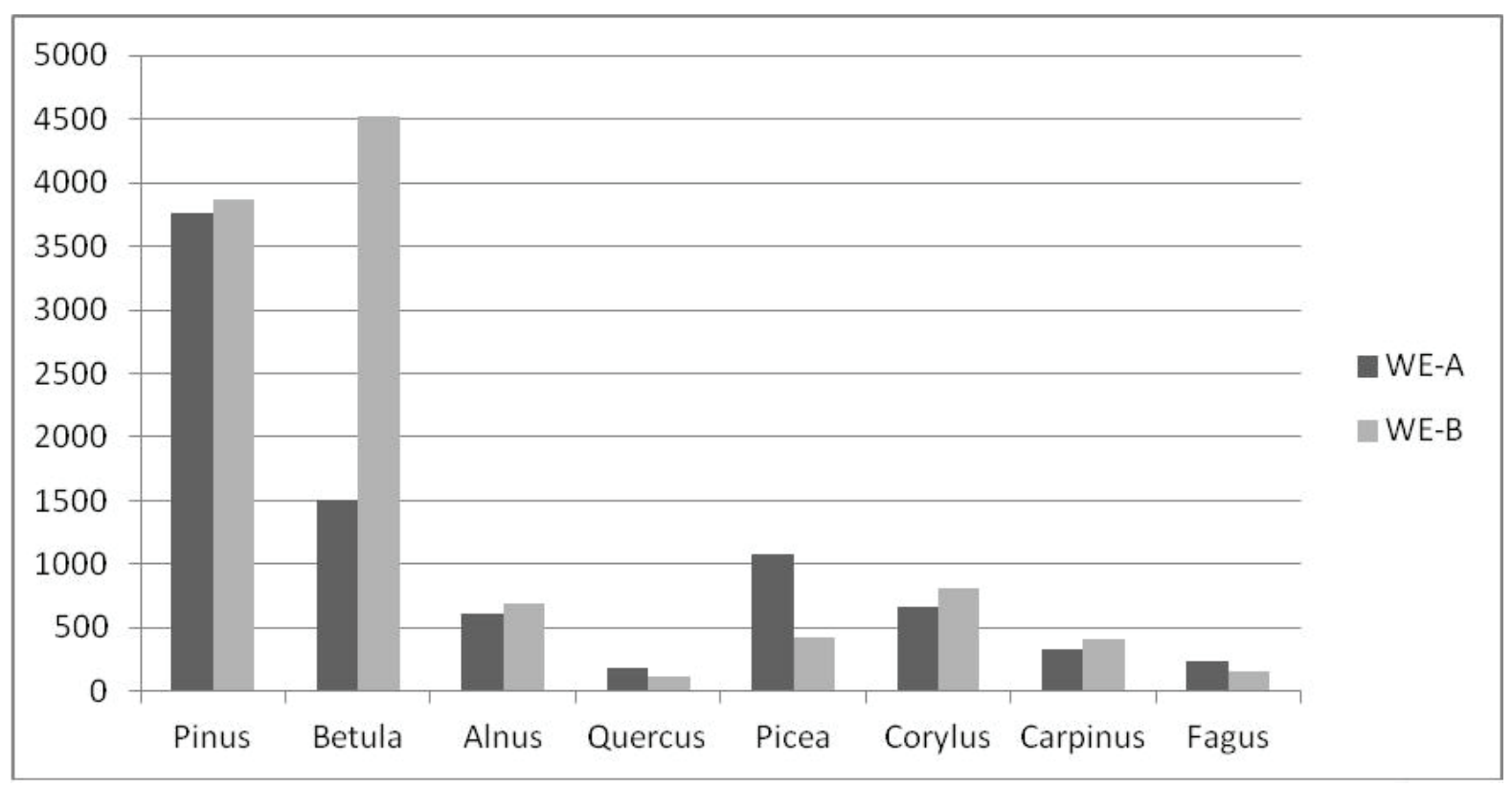

Figure 8. Average values of pollen deposition of selected trees in moss-polsters from Widno Edge site in subsample A and B

A comparison of PAR from Tauber trap with deposition in moss samples from Widno Open site shows differentiation depending on analyzed taxon. Pinus, Quercus, Picea and Fagus are characterized by higher deposition in moss samples, whereas Betula, Alnus and Corylus achieve higher PAR values in traps (Fig. 7). Carpinus pollen achieved low and almost the same values in both sampling media. 


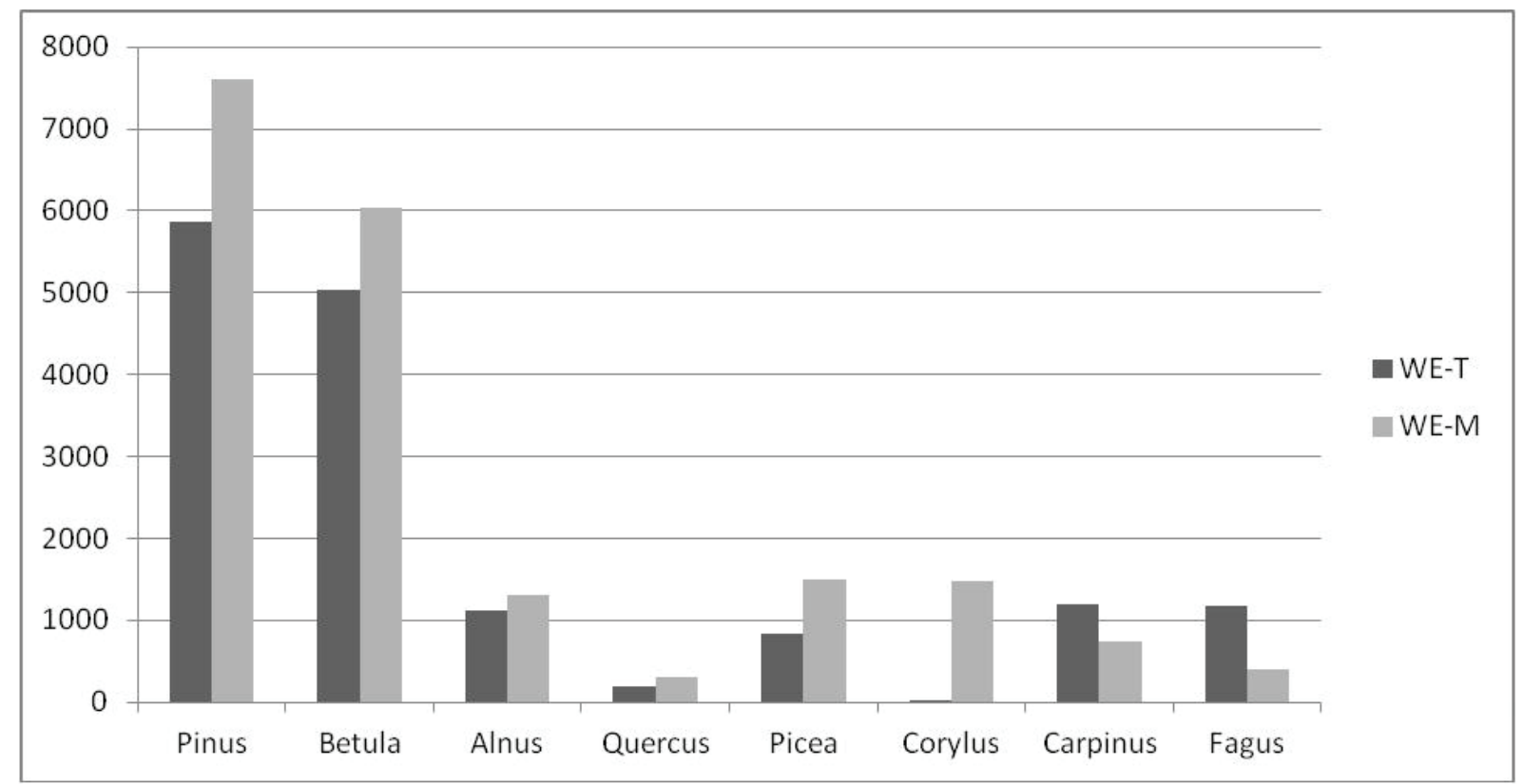

Figure 9. Difference between the pollen deposition in the moss sample M (grains $\mathrm{cm}-2$ ) and PAR in the pollen trap $\mathrm{T}$ (grains cm-2 year-1) for the year of sample collection for sampling pairs from Widno Edge site

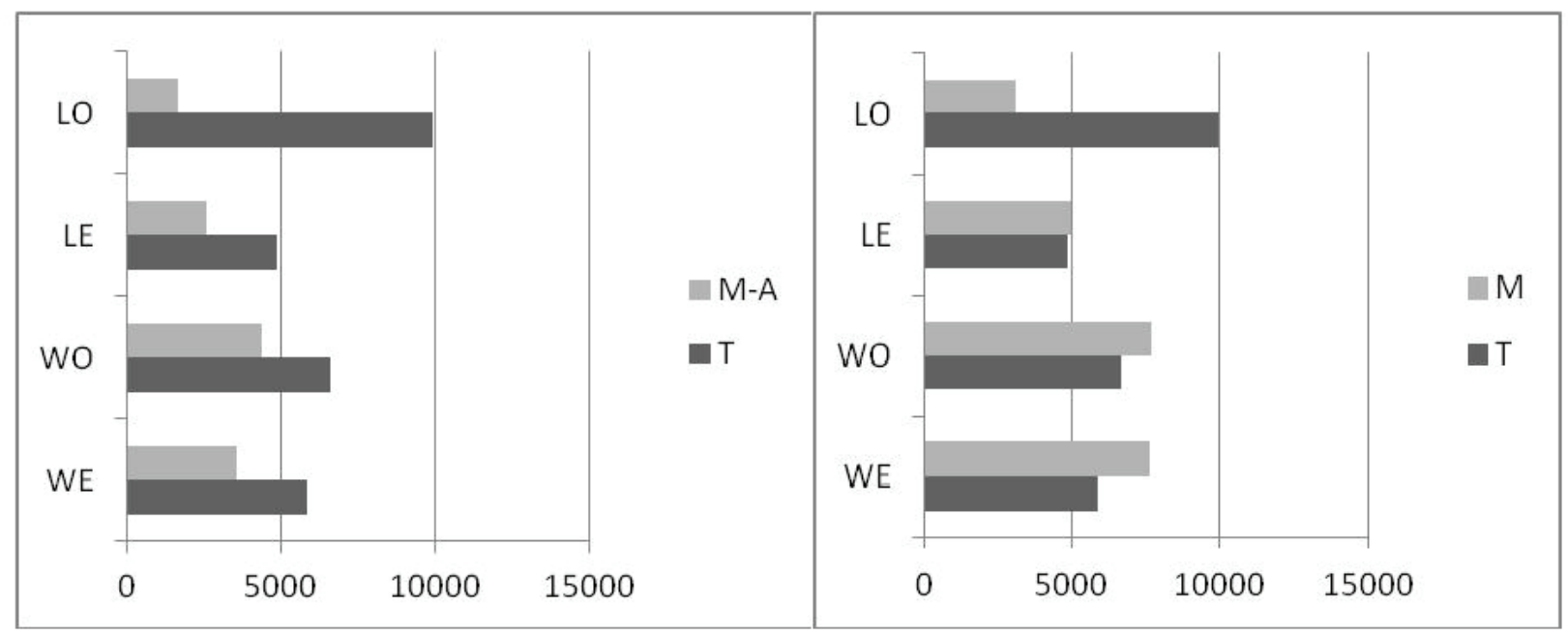

Figure 10. Differences between the Pinus pollen deposition in the moss (grains $\mathrm{cm}^{-2}$ ) (M-A-subsample A, M- subsample A and B) (grains $\mathrm{cm}^{-2}$ ) and PAR in the pollen trap $\mathrm{T}$ (grains $\mathrm{cm}^{-2}$ year-1), LO- Laska Open, LE- Laska Edge, WO- Widno Open, WE- Widno Edge.

\subsection{The site Widno Edge}

The pollen trap was placed in the north-eastern end of Widno, in the vicinity of the hornbeam-oak forest with some admixture of Scots pine, eastern white pine and silver birch.

Considering the average value of the deposition of the five samples should be stated that most analyzed trees ac- cumulate more their pollen grains in basal part of mosssubsample B than in subsample A (Fig. 8).

The pollen accumulated in the moss was equivalent to more than 1 year's pollen deposition in the trap on Widno Edge site with the exception of Carpinus and Fagus (Fig. 9). 


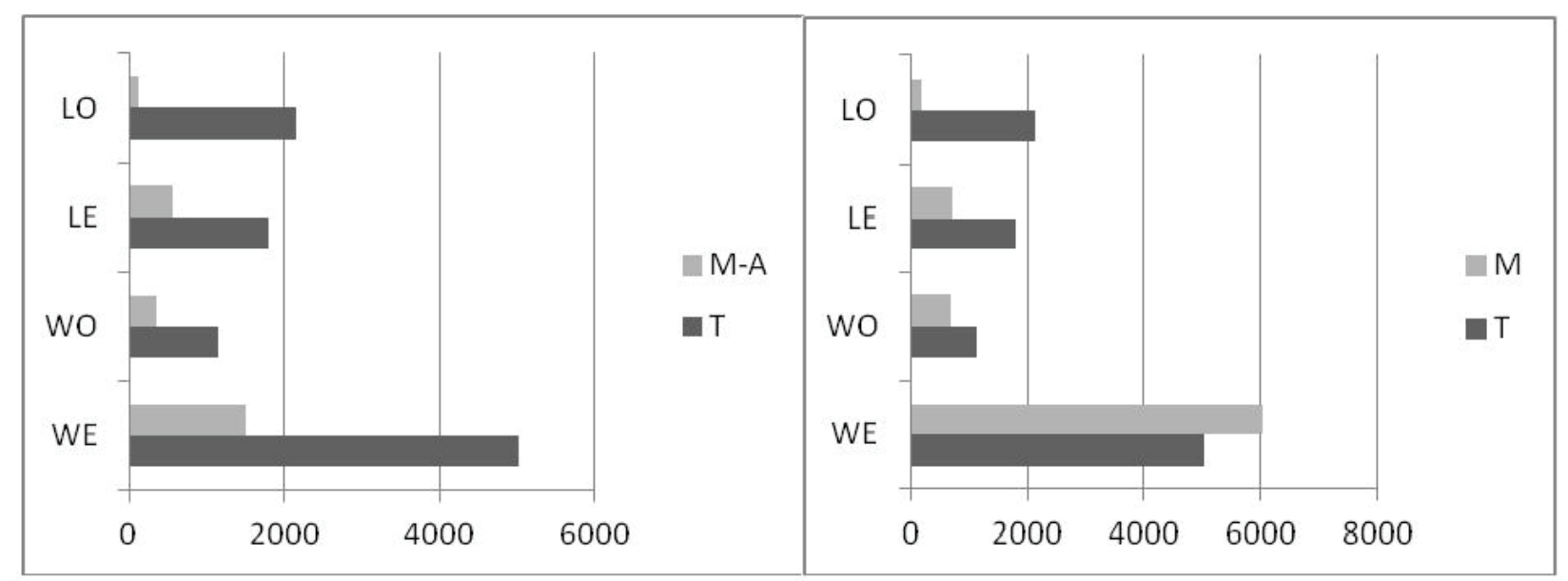

Figure 11. Differences between the Betula pollen deposition in the moss (M-A-subsample A, M- subsample A and B) (grains $\left.\mathrm{cm}^{-2}\right)$ and PAR in the pollen trap $\mathrm{T}$ (grains $\mathrm{cm}^{-2}$ year $^{-1}$ ), LO- Laska Open, LE- Laska Edge, WO- Widno Open, WE- Widno Edge

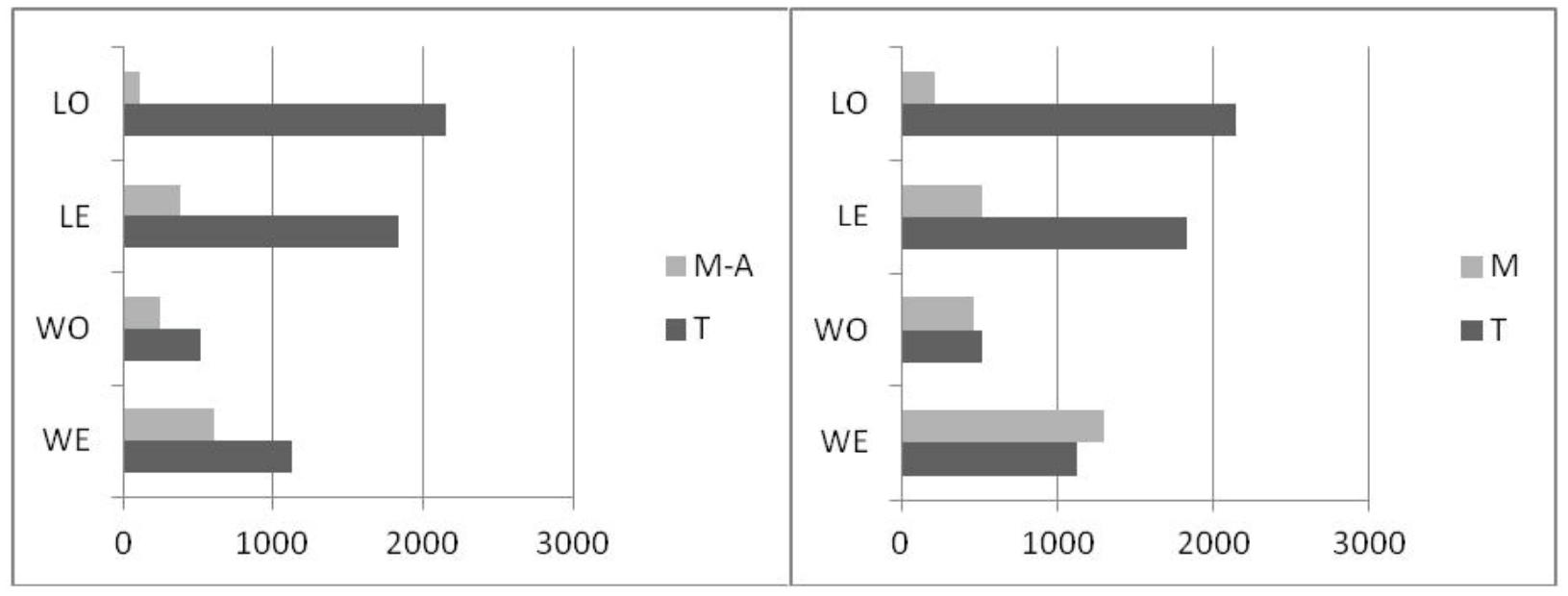

Figure 12. Differences between the Alnus pollen deposition in the moss (M-A-subsample A, M- subsample A and B) (grains $\mathrm{cm}^{-2}$ ) and PAR in the pollen trap (grains $\mathrm{cm}^{-2}$ year $^{-1}$ ), LO- Laska Open, LE- Laska Edge, WO- Widno Open, WE- Widno Edge

\subsection{Representation of selected taxa in moss compared to traps}

The two approaches that were used to estimate the duration of pollen deposition in a moss sample assume that the moss sample has the same trapping efficiency as the pollen trap. The first approach was comparison of total samples (subsample A and B) with pollen accumulation rate (PAR) from trap. The second method based on juxtaposition of pollen accumulation in green gametophytes (Subsample A) with pollen deposition in trap.

Pinus is widely distributed in the region and, because of the abundance of the trees, there are vast quantities of pine pollen in the air. Pinus pollen deposition in the green parts of moss (subsample A) is lower than observed in traps (Fig. 10). The reverse situation is observed if one considers green gametophytes (A) and basal part of moss (B) with the exception of Laska Open (LO) site.

Values of pollen deposition of birch are higher in traps when only green parts of mosses (subsample A) are taking in to account (Fig. 11). Comparing deposition in both subsamples (A and $\mathrm{B}$ ) the reverse results were noted with the exception of Widno Edge station.

Tauber traps from Laska (Laska Open - LO and Laska Edge - LE) contained more pollen grains of Alnus than traps in Widno irrespective of alder abundance in the local vegetation (Fig. 12). Values of pollen deposition of $\mathrm{Al}$ - 
nus in moss are lower than in traps with one exception of Widno Edge station when two subsamples (A and B) are taking into account.

\section{Discussion}

The presented results of the study on the annual pollen deposition include only values for arboreal pollen deposition. In the case of the analysed sites located in the largely afforested area where pine is the most important component of forest plant communities, high contribution of $\mathrm{Pi}$ nus pollen results from the dominance of this component both in the local and regional pollen rain (Prentice et al. 1987; Jackson \& Kearsley 1998). In both sets of results the pollen rain is dominated by Pinus, Betula and Alnus.

The results demonstrate that the pollen deposition in pollen traps can differ considerably from that in a moss adjacent to the trap. The obtained results showed that, Pinus pollen accumulated in the moss usually were equivalent to more than 1 year's pollen deposition in the trap, while for Betula and Alnus the same moss sample contained less than a year of pollen deposition. Räsänen et al. (2004) where, using green mosses sampled down to the mineral soil, suggested that the individual moss sample from the island Hailuoto (Finland) represent between one and two years of pollen loading. However, bisaccate pollen grains tend to be over-represented in moss samples compared to pollen traps. The dominance of pine pollen in the moss polsters as compared to the pollen traps has been mentioned for different localities and different vegetation types (Vermoere et al. 2000; Räsänen et al. 2004; Lazarova et al. 2006) and seems to be a common phenomenon. For example, Bradshaw (1981) and Braggio Morucchio et al. (1988) believe that green moss shoots contain pollen from the last few years whilst Cundill (1985) has considered that such samples may contain only a few months moss growth and therefore a limited period of pollen entrapment. The current study provides evidence which appears to support the latter point of view, especially if we only consider green parts of the moss (subsample A). The moss samples consisted of green gametophytes (A) and basal part of moss (B) sometimes contain pollen from a period a little longer than one year. Pine, spruce, oak and beech deposited more pollen almost always in the subsample A.

There are many potential problems associated with the growth-form and density of the moss. Boyd (1986) suggests that the pollen content of some mosses may reflect the composition of pollen rain more accurately than that of other mosses. The differences in deposition of pollen on gametophytes may to some extent were caused by the fact that the samples were taken from different moss species whose gametophytes had different morphological characteristics. Unfortunately, it was not possible to take sam- ples from identical gametophytes, because there were few mosses near the Tauber traps. The length of the time period covered by the moss depends on the moss type. Where there is a choice of moss taxa, we should perhaps collect one genus for the sake of consistency (Pardoe et al. 2010).

\section{References}

Berglund B.E. \& Ralska-Jasiewiczowa M., 1986, Pollen analysis and pollen diagrams, [in:] B. E. Berglund (ed.) Handbook of Holocene Palaeoecology and Palaeohydrology, John Willey \& Sons, Chichester: 455-484.

Boyd W.E., 1986, The role of mosses in modern pollen analysis: The influence of moss morphology on pollen entrapment, Pollen et Spores 28: 245-255.

Bradshaw R.H.W., 1981, Modern pollen-representation factors for woods in south-east England, Journal of Ecology 69: 45-70.

Braggio Morucchio G., Cornara L., Mariotti M., 1988, Modern pollen rain and vegetation relationship in microinsular Mediterranean environments. I. Zannone Island (Pontian Archipelago - Italy), Pollen et Spores 30: 471-483.

Ceynowa-Giełdon M., 1988, Elementy flory naczyniowej obszarów Borów Tucholskich [w:] Ochrona przyrody Borów Tucholskich, I Konferencja naukowa. Zakład Taksonomii i Geografii Roślin UMK, Zakład Ochrony Środowiska ATR Bydgoszcz, Bydgoskie Towarzystwo Ekologiczne, [ Elements of the vascular flora of the Tuchola Forest [in:] Nature protection of the Tuchola Forest, 1st Scientific Conference. Plant Taxonomy and Geography Department UMK, Department of Environmental Protection ATR Bydgoszcz, Bydgoszcz Ecological Society, Toruń-Bydgoszcz: 82-92.

Cundill P. R., 1991, Comparisons of moss polster and pollen trap data: a pilot study, Grana, 30(2), 301-308, DOI: 10.1080/00173139109431984

Cundill P. R., 1985, The use of mosses in modern pollen studies at Morton Lochs, Fife. Transactions and proceedings of the Botanical Society of Edinburgh 44: 375-383.

Cudill P.R., Austin W.E.N. \& Davies S.E., 2006, Modern pollen from the catchment and surficial sediments of a Scottish sea loch (fjord), Grana 45: 230-238. DOI: 10.1080/00173130600873919

Filbrandt-Czaja A., Deptuła M. \& Nienartowicz A., 2012, Influence of land cover and structure of tree stands on pollen deposition in Zaborski Landscape Park, Ecological Questions 16: 41-49.

Hicks S., 1996, The feasibility of using pollen deposition data as climatic indices, Paläoklimaforschung 20:173187 
Hicks S., 1985, Modern pollen deposition records from Kuusamo. Finland. I. Seasonal and annual variation, Grana 24: 167-181.

Hicks S, Tinsley H, Pardoe H. \& Cundill P.R., 1999, Supplement to the guidelines. European pollen monitoring programme, Oulu University Press, Oulu, Finland.

Hicks S. \& Hyvärinen V-P., 1986, Sampling modern pollen deposition by means of 'Tauber traps': some considerations, Pollen et Spores 28: 219-242

Hicks S., Ammann B., Latałowa M., Pardoe H. \& Tinsley H., 1996, European Pollen Monitoring Programme: project description and guidelines, Oulu University Press, Oulu, Finland.

Hrynowiecka-Czmielewska A. \& Filbrandt-Czaja A., Nienartowicz A., 2007, Modern pollen -vegetation relationships in the Tuchola Forest, Ecological Questions 8: 47-70.

Jackson S. T. \& Kearsley J. B., 1998, Quantitative representation of local forest composition in forest-floor pollen assemblages, Journal of Ecology 86: 474-490.

Kondracki J., 2000, Geografia regionalna Polski, [Regional geography of Poland], Wydawnictwo Naukowe PWN, Warszawa.

Lazarova M., Petrova M. \& Jordanova M., 2006, Pollen monitoring in surface samples in mosses and pollen traps from the Beglika region (W Rhodopes), Phytologia Balcanica 12: 317-325.

Lisitsyna O.V. \& Hicks S., 2014, Estimation of pollen deposition time-span in moss polsters with the aid of annual pollen accumulation values from pollen traps, Grana, 53(3), 232-248, DOI:10.1080/00173134.2014 .916344

Matuszkiewicz W., 1968, Potencjalna roślinność naturalna okolic jeziora Wdzydze (Bory Tucholskie). Materiały Zakładu Fitosocjologii Stosowanej Uniwersytetu Warszawskiego. [Potential natural vegetation of the vicinity of Wdzydze Lake (Tuchola Forest), Materials of the
Phytosociology Department of the Warsaw University], 23, Warszawa - Białowieża.

Nienartowicz A., Filbrandt-Czaja A., Piernik A., Jabłoński P., Kunz M. \& Deptuła M., 2011, Modern pollen rain in heathlands and adjacent forest phytocoenoses in Northern and Central Poland, Ecological Questions 15: $127-151$.

Pardoe H., Giesecke T., Van der Knaap W., Svitavska' Svobodova H., Kvavadze E., Panajiotidis S., Gerasimidis A., Pidek I., Zimny M., Święta-Musznicka J., Latałowa M., Noryśkiewicz A., Bozilova E., Tonkov S., Filipova-Marinova M., Van Leeuwen J. \& Kalnina L., 2010, Comparing pollen spectra from modified Tauber traps and moss samples: examples from a selection of woodlands across Europe, Vegetation History and Archaeobotany 19: 271-283.

Prentice I.C., Berglund B.E. \& Olsson T., 1987, Quantitative forest composition sensing characteristics of pollen samples from Swedish lakes, Boreas 16: 43-54.

Räsänen S., Hicks S. \& Odgaard B.V., 2004, Pollen deposition in mosses and in a modified "Tauber trap" from Hailuoto, Finland: What exactly do the mosses record? Review of Palaeobotany and Palynology 129: 103-116. doi:10.1016/j.revpalbo.2003.12.001.

Stockmarr J. 1971. Tablets with spores used in absolute pollen analysis, Pollen et Spores 13: 615-621

Tauber H., 1974, A statistic non-overload pollen collector. New Phytologist 73: 359-369

Tonkov S., Hicks S., Bozilova E. \& Atanassova J., 2001, Pollen monitoring in the central Rila Mountains, Southwestern Bulgaria: Comparisons between pollen traps and surface samples for the period 1993-1999, Review of Palaeobotany and Palynology 117: 167-182. doi:10.1016/S0034-6667(01)00085-9

Vermoere M., Vanhecke L., Waelkens M. \& Smets E., 2000, A comparison between modern pollen spectra of moss cushions and Cundill pollen traps, Grana 39: 146-158. doi:10.1080/001731300300045328. 